\title{
DETECTION OF Cryptosporidium SP. IN NON DIARRHEAL FAECES FROM CHILDREN, IN A DAY CARE CENTER IN THE CITY OF SÃO PAULO, BRAZIL
}

\author{
Therezinha T. CARVAlHO-ALMEIDA(1), Pedro Luis S. PINTO(1), Celma Maria S. QUADROS(1), Domingas M.A.G.V. TORRES(1), \\ Hermínia Y. KANAMURA(2) \& Angélica Maria CASIMIRO(3)
}

\begin{abstract}
SUMMARY
The protozoan Cryptosporidium sp. has been frequently detected in faeces from children with persistent diarrhoea. This work achieved to investigate an outbreak of cryptosporidiosis, in a day care center, attending children of high socio-economic level, between 0 and six years old. The outbreak was detected through the network of public health, when stool samples, not diarrhoeic, were examined at the Parasitology Service of the Adolfo Lutz Institute. Among the 64 examined children, 13 (20.3\%) showed oocysts of Cryptosporidium sp. in the faeces examined by Kinyoun technique: seven children one year old, three, two years old and three, three years old. Among the 23 examined adults, only a 22 years old woman, possibly having an immunocomprometiment, was positive. Clinical and epidemiological aspects were investigated by questionnaires, highlighting the occurrence of the outbreak in a very dry period.
\end{abstract}

KEYWORDS: Cryptosporidium sp.; Cryptosporidiosis; Day care center.

\section{INTRODUCTION}

The coccidian Protozoa, Cryptosporidium sp., was initially thought to be the causative agent of diarrhoea diseases only in immunocompromised patients (HIV positive). It uses to infect the intestinal cells and to cause acute self limited diarrhoea in immunocompetent host, and chronic severe and prolonged diarrhoea in immunocompromised persons $s^{9,34}$. In humans, it accounts for up to $20 \%$ of all cases of childhood diarrhoea in developing countries. Although once considered rare Cryptosporidium is now recognised as a significant pathogen in child care settings ${ }^{26}$. Cryptosporidial symptomatic infection is much more common in young children than in adults ${ }^{21}$. Data about human cryptosporidiosis have originated mainly from persons infected with the human immunodeficiency virus (HIV), travelers, waterborne outbreaks, community and day care center outbreaks $^{18,25}$. In the last ones, occurrence of Cryptosporidium sp. may be frequent but diagnosis remains not determined.

Diarrhoea outbreaks due to $C$. hominis (formerly known as $C$. parvum human genotype or $C$. parvum type I) ${ }^{24}$ and $C$. parvum have been reported among children in day care centers, indicating that this protozoan is highly infectious ${ }^{12,32}$. In Brazil, little is known about the ecology of these parasites. A survey among physicians working in the city of Porto Alegre, Rio Grande do Sul, Brazil, concluded that cryptosporidiosis is badly known and as consequence, the prevalence should be underestimated in our country ${ }^{37}$. Another survey reported that among the laboratories, only a few make the clinical diagnostic for Cryptosporidium as a routine procedure and the other laboratories only make the microscopic diagnostic when requested by the physician $^{36}$.

Persons become infected with Cryptosporidium spp. through the ingestion of oocysts excreted in human or animal faeces. Infection can occur from person-to-person, animal-to-person, and through environmental transmission.

Studies have demonstrated that cryptosporidiosis is endemic in many tropical regions and that Cryptosporidium is one of the three major agents of parasitic infectious diarrhoea affecting children between 0 and 5 years of age, in Brazil ${ }^{13,29}$.

The detection of the present delayed outbreak was possible because of the awareness of the Enteroparasitosis Section of the Service of Parasitology of Adolfo Lutz Institute in improving the diagnostic techniques and study the epidemiological aspects of enteric opportunistic and emergent parasites in our environment.

This study aimed to investigate the presence of Cryptosporidium sp. after the occurrence of a diarrhoea outbreak in a day care center, which attends 91 children from four to 72 months of age, in São Paulo City, Brazil. 


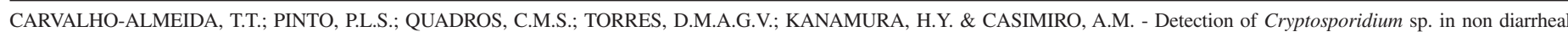
faeces from children, in a day care center in the city of São Paulo, Brazil. Rev. Inst. Med. trop. S. Paulo, 48(1): 27-32, 2006.

\section{MATERIALS AND METHODS}

At the time of this study, the center was taking care of 91 children aged four through 72 months old. A single stool specimen was collected from each of 64 children $(70.32 \%)$ and all staff members $(n=23)$.

The day care center is located in a wealthy region of the city of São Paulo. The building is a three-floor house, with washable pavement or parquet wood block floor in its rooms. There is a sand tank where children of all ages can play together. The day care has a good standard of hygiene, providing to the children food cooked in its own kitchen and both, filtered tap water or mineral water from gallons.

Stool samples from these 64 children were collected by parents or guardians. Faeces were placed into disposable plastic cups without any preservatives, refrigerated at $4{ }^{\circ} \mathrm{C}$ and delivered to the laboratory between 12 and 24 hours, from 30 August to 26 September, 2001. Stool samples from 23 employees, age varying from 21 to 50 years old, were also submitted to examination. The routine procedures for the stool samples at the laboratory for parasitological diagnostic is: i) stool preserved in $10 \%$ buffered formalin is submitted to spontaneous sedimentation, to investigate cysts and eggs and formol-ether concentration to exam intestinal coccidian, followed by screening with auramine and visualisation in fluorescence microscope. When positive for oocysts of Cryptosporidium sp., smears were stained by the Kinyoun method, a modified Ziehl-Neelsen technique ${ }^{7}$ to confirm the result, ii) stool with no preservative is submitted to larvae examination by Rugai methods as described previously ${ }^{8}$.

Fifty samples consisted of unformed and formed faeces, being collected from eight to 10 days after the occurrence of the first case of diarrhoea. The remaining 14 samples were collected approximately 35 days after the occurrence of the diarrhoea episodes.

Comprehensive self-administered questionnaires were distributed to be answered at home by mother or the person responsible for the child to characterise the children illnesses and verify risk factors for acquiring the infection. The questionnaire included items on: i) host factors: age, sex, diarrhoea, number of stool emission per day, fever, vomit, another symptoms and use of medication; ii) socio-demographic factors: parent's occupation, mother's education degree, familial monthly income, number of household members, number of household members who had diarrhoea at the time of the outbreak, number of days and hours the child spends at day care centre; iii) zoonotic factors: number and type of pets owned by the household, contact with livestock; iv) environmental factors: diet (consumption of raw salads, non-peeled fruits and raw milk), if child uses to play in public parks and sand tanks, source and treatment of drinking water.

\section{RESULTS}

Out of 64 examined children, $13(20.3 \%)$ were positive for Cryptosporidium sp., being seven $(10.9 \%)$ one year old; three children $(4.7 \%)$ two years old and three children three years old (Table 1). Among the 23 examined adults, only one individual was positive for Cryptosporidium sp., a 22 year-old woman, who had received liver transplantation. She presented diarrhoea as symptom and had to be hospitalised.

Stratifying by age, the children who had positive exam for Cryptosporidium, it results in $46.7 \%$ (7/15) of one year old children, $25 \%(3 / 12)$ of two years old and $17.6 \%(3 / 17)$ aged three years.

Nine out of the 13 positive samples, consisting of unformed and formed faeces, were collected from eight to 10 days after the occurrence of the first case of diarrhoea. The remaining five positive samples were collected approximately 35 days after the occurrence of the diarrhoea episodes.

We got back 47 (51.7\%) answered questionnaires. Stool samples from 30 children were submitted to the parasitological exam but parents did not answer the questionnaire while we had data from 14 children which did not the faecal examination. Data from seven of 13 positive (54\%) and 29 of $53(54.7 \%)$ negative children for Cryptosporidium sp. were analysed (Table 1). All these seven children with positive result reported episodes of diarrhoea, four had low fever and three had vomit.

Table 1

Results of the parasitological exam for Cryptosporidium among children who attend a day-care-center distributed by age, sex and answer to a questionnaire

\begin{tabular}{|c|c|c|c|c|c|c|c|c|c|c|c|}
\hline \multirow[b]{3}{*}{ Age (years) } & \multicolumn{4}{|c|}{ Questionnaires answered } & \multicolumn{4}{|c|}{ Questionnaires not answered } & \multirow{3}{*}{$\begin{array}{l}\text { Total } \\
\text { Exams }\end{array}$} & \multirow{2}{*}{\multicolumn{2}{|c|}{$\begin{array}{l}\text { Questionnnaires answered } \\
\text { Exam not done }\end{array}$}} \\
\hline & \multicolumn{2}{|c|}{ Cryptosporidium } & \multicolumn{2}{|c|}{$C$. negative } & \multicolumn{2}{|c|}{ Cryptosporidium } & \multicolumn{2}{|c|}{$C$. negative } & & & \\
\hline & W & $\mathrm{M}$ & $\mathrm{W}$ & M & $\mathrm{W}$ & M & W & M & & W & M \\
\hline$<1$ & 0 & 0 & 0 & 1 & 0 & 0 & 2 & 0 & 3 & 0 & 0 \\
\hline 1 & 2 & 1 & 1 & 3 & 3 & 1 & 3 & 1 & 15 & 0 & 0 \\
\hline 2 & 2 & 1 & 5 & 1 & 0 & 0 & 2 & 1 & 13 & 1 & 1 \\
\hline 3 & 0 & 1 & 5 & 2 & 2 & 0 & 6 & 1 & 17 & 2 & 0 \\
\hline 4 & 0 & 0 & 4 & 0 & 0 & 0 & 3 & 1 & 7 & 1 & 4 \\
\hline 5 & 0 & 0 & 0 & 0 & 0 & 0 & 1 & 1 & 2 & 0 & 2 \\
\hline 6 & 0 & 0 & 2 & 1 & 0 & 0 & 1 & 1 & 5 & 1 & 1 \\
\hline 7 & 0 & 0 & 1 & 0 & 0 & 0 & 1 & 0 & 2 & 1 & 0 \\
\hline Total & 4 & 3 & 18 & 8 & 5 & 1 & 19 & 6 & 64 & 6 & 8 \\
\hline Adult $*$ & & & & & 1 & 0 & 22 & 2 & 23 & & \\
\hline
\end{tabular}

Questionnaire was not applied to adults; $\mathrm{W}=$ woman; $\mathrm{M}=$ male. 
Other reported symptoms were abdominal cramps, anorexia and fatigue. We documented that children without parasitologically confirmed infection also had symptoms in the same period: diarrhoea (10 children), low fever (two children) and vomit (one child). Among the infected children, three $(42.85 \%)$ had between one to four episodes and four $(66.66 \%)$ ranged from five to eight stool emissions per day. Among the 10 children with diarrhoea but negative for Cryptosporidium in the faecal examination, eight had from one to four emissions per day and two from five to eight episodes.

There was no association of Cryptosporidium and other intestinal parasites. Nevertheless, Giardia duodenalis, was found in two boys, aged one and three years old. One woman presented coinfection with G. duodenalis and Entamoeba histolytica/E. dispar, another one was infected with $E$. coli and a male adult had infection with Blastocystis.

Among the seven Cryptosporidium positive children, in the household of five of them, other persons (two children and five adults) had diarrhoea after the child-case, but none submitted faeces for parasitological examination.

The average time of daily permanence in the day care setting was less than five hours for three Cryptosporidium positive children (42.85\%) and 14 Cryptosporidium negative one (37.83\%); period of time ranging from five to seven hours for one positive child and 15 negative children $(40.54 \%)$ and more than seven hours a day, for three positive $(42.85 \%)$ and eight $(21.62 \%)$ negative children.

Almost all children $(78.26 \%)$ had the habit to put hands in mouth.

The water consumed at the houses is tap filtered water $(55 \%)$, bottled mineral $(26 \%)$, mineral water from gallon $(12 \%)$ and tap purified water $(6 \%)$.

Thirty eight $(83 \%)$ of the households have incomes above 10 minimum wages per month; 42 mothers $(91 \%)$ have university degree. Twenty three $(50 \%)$ were families constituted of three persons, 21 (45.65\%) families had four or more persons and two families $(4.43 \%)$ have only two persons. Twenty two $(47.82 \%)$ children were unique child, $18(39.13 \%)$ had one brother or sister, four $(8.69 \%)$ had two brothers or sisters and one $(2.17 \%)$ had three brothers or sisters.

The presence of animal pets in the household was similar for children with $(28.57 \%)$ and without $(28.20 \%)$ cryptosporidiosis.

\section{DISCUSSION}

The present study started after a request of an UVS (Basic Unit of Surveillance) to investigate diarrhoeal cases in children attending a day-care-center. The faecal samples were sent to Adolfo Lutz Institute following the established flux by the CVE-DTA (Epidemiological Surveillance of Waterborne Diseases). According to this fluxogram, $10 \%$ of faecal samples must be analysed to investigate the presence of Rotavirus, Pathogenic Enterobacterias and Parasites. The exam of the first samples revealed the presence of Cryptosporidium sp. oocysts and then, the UVS continued to delivery non diarrhoeal faecal samples during 25 days after the first diahrroeal case occurred. Unusually, were detected five more children infected with Cryptosporidium.

The stool samples submitted to parasitological examination in this study, did not consist of diarrhoeal samples, what lead us to think that the faecal collection was made after the peak of the outbreak. Despite of this, the prevalence $(20.3 \%)$ was high in this delayed notified outbreak, if compared to another Brazilian studies. There are two studies

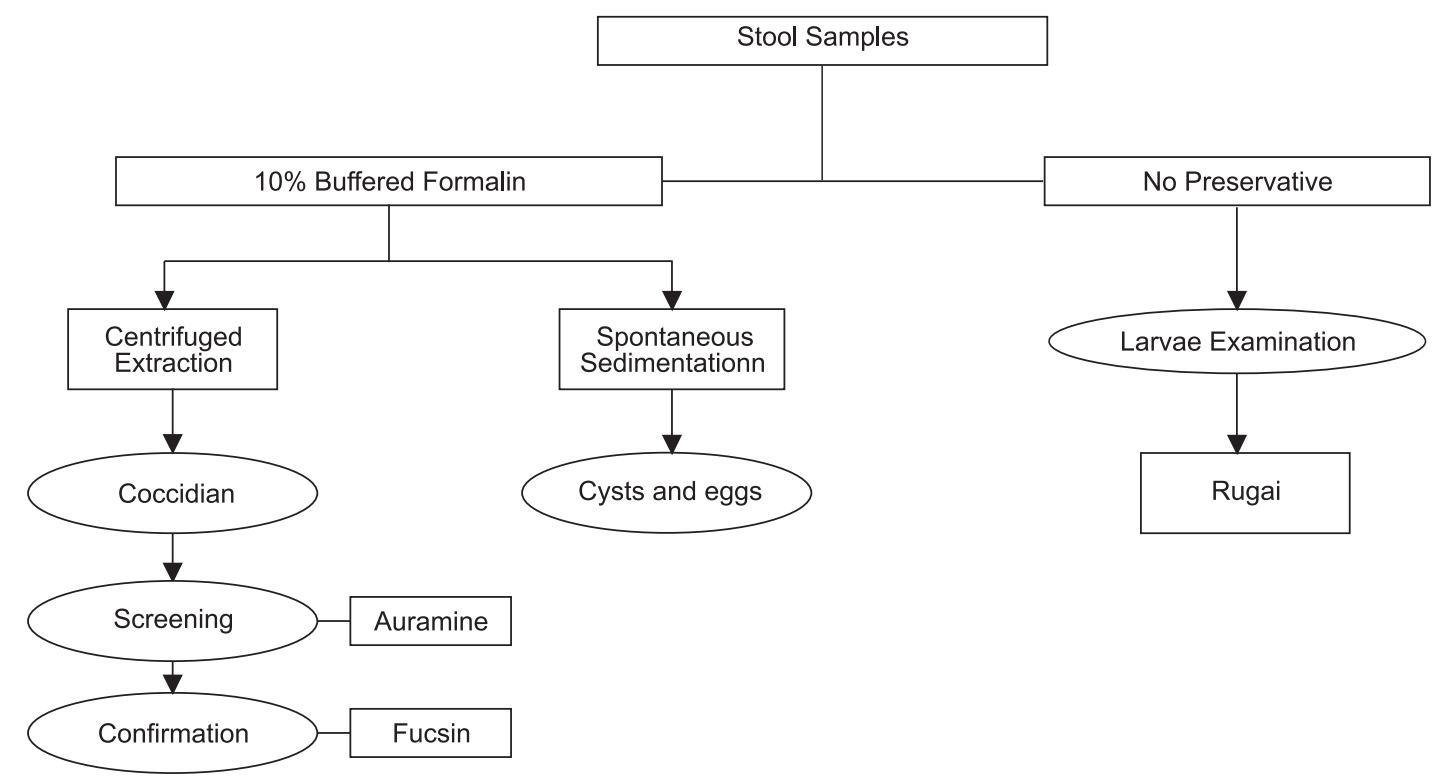

Fig. 1 - Fluxogram of the routine procedures which the stool samples are submitted at the laboratory of Adolfo Lutz Institute, for parasitological diagnostic. 


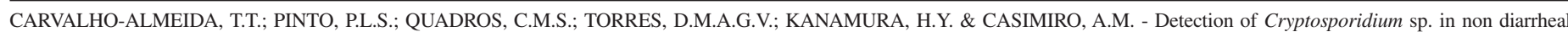
faeces from children, in a day care center in the city of São Paulo, Brazil. Rev. Inst. Med. trop. S. Paulo, 48(1): 27-32, 2006.

that report Cryptosporidium in diarrhoeic and non diarrhoeic faeces. One registered $4.4 \%$ of prevalence mainly in children from 0 to three years old, in Goiânia, Goiás ${ }^{3}$. The other found $3.3 \%$ of positivity in children less than 10 years old in Rio de Janeiro ${ }^{5}$. All the other works in literature were done with children presenting acute diarrhoea. A two-year study in Porto Alegre, Rio Grande do Sul, revealed $20.0 \%$ of infection with Cryptosporidium in children between 0 and 24 months old $^{2}$. In Goiânia, Goiás, the prevalence was $14.4 \%$ among children from two weeks to 10 years of age ${ }^{30}$. In the city of São Paulo, among children with acute diarrhoea attended in hospital the incidence was $14.43 \%$ being more frequent among children from six to 12 months old $^{22}$. The incidence in children from one to two years old, in Belém, Pará, was $2.7 \%{ }^{20}$ and $5.2 \%{ }^{21}$. In Recife, Pernambuco, was $6.4 \%$. In Campinas, São Paulo, a study in eight day care centres revealed $6.4 \%$ of infected children between 0 to 12 months old ${ }^{12}$. In Maringá, Paraná, Cryptosporidium was the second parasite agent more frequent $(6.6 \%)$ in children aged 12 to 24 months $^{23}$. The highest prevalence ever registered for Cryptosporidium infection is $85.1 \%$ in Criciúma, Santa Catarina ${ }^{35}$.

In our delayed notified outbreak, $76.9 \%$ of Cryptosporidium infection occurred in children under two years old (24 months), and $23.1 \%$ in children three years old (36 months). This is in agreement with reports by others ${ }^{14,20,27}$. For the adult group, the infection was limited to the immunocompromised one.

Among the 13 positive children, we had questionnaires answered from seven (Table 1). Although we did not examine stools of family members, it was reported that in the house of five of the families (71.4\%), other cases of diarrhoea occurred in the same period, in five adults and two children, suggesting some degree of secondary spread. This percentage is higher than the $27 \%$ found in another study among additional childhood cases of diarrhoea for families where the index case attend day care center in Goiânia ${ }^{30}$. The presence of a child under five years old in the household was significantly associated with postoutbreak cryptosporidiosis in the neighborhood case-control study in Milwaukee $^{28}$. The contact with children from two to 11 years old suffering from diarrhoea was considered a risk factor to immunocompetent individuals in USA ${ }^{32}$. Those observations confirm that Cryptosporidium can cause outbreaks of diarrhoea in day care settings and can be spread within households.

Questionnaires administered to parents revealed no association with water, travel, frequency to public parks and sand tanks or child's habit of putting finger in mouth.

Contact with pets did not seem to be related to the occurrence of the infection. On the other hand, contact with livestock was much higher in children with $(75 \%)$ cryptosporidiosis than in children without $(8.1 \%)$ infection. It might suggest a risk factor in this small studied population.

Several studies show that cryptosporidiosis is a highly seasonal disease occurring nearly only during the rainiest months ${ }^{1,12,16,19,27,30}$, but the occurrence of this outbreak was during an unusual dry period for the city. In August, the monthly rain precipitation was $58.72 \mathrm{~mm}^{33}$.

It was not possible to determine whether the infective source was endogenous or exogenous. If one could analyse the epidemic curve it will lead to suppose that one child came infected to the day care setting causing person-to-person transmission among the most susceptible subjects, like children less than two years old and the immunosupressed adult.

As the detection of the infective cases were done after the peak of the infection, one can not say if the transmission had a unique source, as water transmission or if it was a person-to-person transmission.

All affected children, their families and staff members were immunocompetent. The only immunocompromised adult was a 22 yearold woman, who had been submitted to a liver transplantation, presented Cryptosporidium infection and had diarrhoea after the first cases of diarrhoea in children. This observation is in accordance to other Brazilian authors who named kidney transplantation as a risk factor for acquiring cryptosporidiosis ${ }^{4,11,17}$.

It is presumed that this outbreak occurred as a result of person-toperson transmission of the protozoa in the day-care center, stressing the importance of handwashing among staff and older children. Another outbreak in a day care center was detected in the same region of the City of São Paulo, in April 2001 ${ }^{15}$, when 25 isolates were genotyped as C. parvum human genotype (now renamed as C. hominins ${ }^{24}$ ).

No definite proof could be found to demonstrate either the source of the outbreak or the route of transmission. However, some features suggest that a common source of infection was unlikely and that personto-person spread occurred.

Cryptosporidiosis should be considered in the differential diagnosis of young children with diarrhoeal illness, especially those attending a day care facility.

These findings highlight the need of an active surveillance of diarrhoeal diseases associated with molecular tools, in order to determine the epidemiology of cryptosporidiosis in our environment and make guidelines to prevent the infection, once, until now, no successful drug is known. So, further studies are needed to determine risk factors and provide insight into the existence of potential environmental sources.

\section{RESUMO}

\section{Detecção de Cryptosporidium sp. em fezes não diarréicas de crianças, em uma escola de educação infantil de São Paulo, Brasil}

O protozoário Cryptosporidium sp. tem sido detectado com freqüência em fezes de crianças com diarréia persistente. Este trabalho teve como objetivo investigar um surto de criptosporidiose, em uma escola de educação infantil, que atende crianças de classe média alta, de 0 a seis anos de idade. O surto foi detectado a partir de amostras fecais não diarréicas encaminhadas ao Instituto Adolfo Lutz através da rede de saúde pública. Das 64 crianças 13 (20,3\%) apresentaram oocistos de Cryptosporidium nas fezes, examinadas pelo método de Kinyoun, sendo sete crianças com um ano de idade, três com dois anos de idade e três, com três anos de idade. Dos 23 adultos examinados, apenas uma mulher de 22 anos, com possível imunocomprometimento, foi positiva. Aspectos epidemiológicos e clínicos foram investigados 


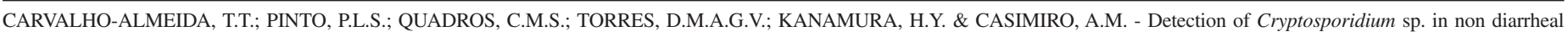
faeces from children, in a day care center in the city of São Paulo, Brazil. Rev. Inst. Med. trop. S. Paulo, 48(1): 27-32, 2006.

por meio de questionários, ressaltando-se que o surto ocorreu em período muito seco.

\section{REFERENCES}

1. AGNEW, D.G.; LIMA, A.A.M.; NEWMAN, R.D. et al. - Cryptosporidiosis in northeastern Brazilian children: association with increased diarrhea morbidity. J. infect. Dis., 177: 754-760, 1998.

2. CANTALICE NETO, A.F.; ZIM, M.C.A.; MACHADO, R.S.; FRATINI, F.G. \& SILVA, A.P. - Criptosporidiose e diarréia persistente. J. Pediat. (Rio de J.), 74: 143-148, 1998

3. CARNEIRO, J.R.; RODRIGUES, N.; LIMA, J.D. \& EVANGELISTA, P.L. - Prevalência da criptosporidiose em crianças procedentes da região metropolitana de GoiâniaGO. Rev. Pat. trop., 24: 243-253, 1995.

4. CHIEFFI, P.P.; SENS, Y.A.S.; PASCHOALOTTI, M.A. et al. - Infection by Cryptosporidium parvum in renal patients submitted to renal transplant or hemodialysis. Rev. Soc. bras. Med. trop., 31: 333-337, 1998.

5. DA SILVA, S.; DA SILVA, S.P.; GOUVEIA, Y. DE S. et al. - Ocorrência de Cryptosporidium sp. em amostras fecais de crianças, menores de 10 anos de idade, com indicaçäo clínica de Rotavírus. Rev. Soc. bras. Med. trop., 36: 421-423, 2003.

6. DA SILVA, G.A.P.; MAGALHÃES, M.; DE OLIVEIRA, A.M.A. \& MELO, V.M. Diarréia aguda do lactente associada ao Cryptosporidium sp., na cidade de Recife. J. Pediat. (Rio de J.), 70: 44-47, 1994.

7. DE CARLI, G.A. \& MOURA, H. - Métodos de coloração para coccídios intestinais. In: DE CARLI, G.A. Parasitologia clínica. São Paulo, Atheneu, 2001. p. 223-263.

8. DIAS, R.M.D.S.; MANGINI, A.C.S.; TORRES, D.M.A.G.V. et al. - Cryptosporidiosis among patients with acquired immunodeficiency syndrome (AIDS) in the county of São Paulo, Brazil. Rev. Inst. Med. trop. S. Paulo, 30: 310-312, 1988.

9. DIETZ, V.; VUGIA, D.; NELSON, R. et al. - Active, multisite, laboratory-based surveillance for Cryptosporidium parvum. Amer. J. trop. Med. Hyg., 62: 368-372, 2000 .

10. DillinghAM, R.A.; LIMA, A.A. \& GUERRANT, R.L. - Cryptosporidiosis: epidemiology and impact. Microbes Infect., 4: 1059-1066, 2002.

11. FERREIRA, M.S. \& BORGES, A.S. - Some aspects of protozoan infections in immunocompromised patients: a review. Mem. Inst. Oswaldo Cruz, 97: 443-457, 2002 .

12. FRANCO, R.M.B. \& CORDEIRO, N.S. - Giardiose e criptosporidiose em creches no Município de Campinas, SP. Rev. Soc. bras. Med. trop., 29: 585-591, 1996.

13. GATEI, W.; GREENSILL, J.; ASHFORD, R.W. et al. - Molecular analysis of the $18 \mathrm{~S}$ rRNA gene of Cryptosporidium parasites from patients with or without human immunodeficiency virus infections living in Kenya, Malawi, Brazil, the United Kingdom, and Vietnam. J. clin. Microbiol., 41: 1458-1462, 2003.

14. GENNARI-CARDOSO, M.L.; COSTA-CRUZ, J.M.; DE CASTRO, E.; LIMA, L.M. \& PRUDENTE, D.V. - Cryptosporidium sp. in children suffering from acute diarrhea at Uberlândia City, State of Minas Gerais, Brazil. Mem. Inst. Oswaldo Cruz, 91: 551-554, 1996.

15. GONÇALVES, E.M.N. - Cryptosporidium parvum: avaliação de métodos diagnósticos e aspectos epidemiológicos. São Paulo, 2002. (Dissertação de Mestrado - Instituto de Ciências Biomédicas da Universidade de São Paulo).

16. GUERRANT, D.I.; MOORE, S.R.; LIMA, A.A. et al. - Association of early childhood diarrhea and cryptosporidiosis with impaired physical fitness and cognitive function four-seven years later in a poor urban community in northeast Brazil. Amer. J. trop. Med. Hyg., 61: 707-713, 1999.
17. JABUR. J.; MIORIN, P.; SILVA, L.A. et al. - Criptosporidiose e outras enteroparasitoses em pacientes submetidos a transplante renal ou hemodiálise J. bras. Nefrol., 18: 239-242, 1996.

18. LEAV, B.A.; MACKAY, M. \& WARD, H.D. - Cryptosporidium species: new insights and old challenges. Clin. infect. Dis., 36: 903-908, 2003.

19. LIMA, A.A.M.; MOORE, S.R.; BARBOZA JR., M.S. et al. - Persistent diarrhea signals a critical period of increased diarrhea burdens and nutritional shortfalls: a prospective cohort study among children in northeastern Brazil. J. infect. Dis., 181: 1643-1651, 2000 .

20. LINHARES, A.C.; FREITAS, R.B.; GABBAY, Y.B. et al. - Incidência das diarréias infantis agudas em um bairro periférico de Belém, Pará: fase preparatória de um futuro estudo de campo com uma vacina contra rotavirus. J. Pediat. (Rio de J.), 66: 205-210, 1990.

21. LOUREIRO, E.C.B.; LINHARES, A.C. \& MATA, L. - Criptosporidiose em crianças de 1 a 2 anos de idade, com diarréia aguda em Belém, Pará, Brasil. Mem. Inst. Oswaldo Cruz, 84: 117-122, 1989.

22. MANGINI, A.C.S.; DIAS, R.M.D.S.; GRISI, S.J.F.E. et al. - Parasitismo por Cryptosporidium sp. em crianças com diarréia aguda. Rev. Inst. Med. trop. S. Paulo, 34: 341-345, 1992.

23. MOITINHO, M.L.R.; ROBERTO, A.C.B.S. \& MARTINS, M.R. - Ocorrência de Cryptosporidium sp. em fezes diarréicas de crianças do Município de Maringá, PR. Acta bioquim. clin. Lat.-amer., 33: 249-253, 1999.

24. MORGAN-RYAN, U.; FALL, A.; WARD, L.A. et al. - Cryptosporidium hominis n. sp. (Apicomplexa: Cryptosporidiidae) from Homo sapiens. J. euk. Microbiol., 49: 433440, 2002.

25. MORGAN, U.; WEBER, R.; XIAO, L et al. - Molecular characterization of Cryptosporidium isolates obtained from human immunodeficiency virus-infected individual living in Switzerland, Kenya, and the United States. J. clin. Microbiol., 38: 1180-1183, 2000 .

26. NCHITO, M.; KELLY, P.; SIANONGO, S. et al. - Cryptosporidiosis in urban Zambian children: an analysis of risk factors. Amer. J. trop. Med. Hyg., 59: 435-437, 1998.

27. NEWMAN, R.D.; SEARS, C.L.; MOORE, S.R. et al. - Longitudinal study of Cryptosporidium infection in children in northeastern Brazil. J. infect. Dis., 180: $167-175,1999$.

28. OSEWE, P.; ADDISS, D.G.; BLAIR, K.A. et al. - Cryptosporidiosis in Wisconsin: a case-control study of post-outbreak transmission. Epidem. Infect., 117: 297-304, 1996.

29. OSHIRO, E.T.; DORVAL, M.E.C.; NUNES, V.L.B.; SILVA, M.A. \& SAID, L.A. Prevalência do Cryptosporidium parvum em crianças abaixo de 5 anos, residentes na zona urbana de Campo Grande, MS, Brasil. Rev. Soc. bras. Med. trop., 33: 277280, 1996.

30. PEREIRA, M.G.C.; ATWILL, E.R.; BARBOSA, A.P.; SILVA, S.A. \& GARCIA-ZAPATA, M.T.A. - Intra-familial and extra-familial risk factors associated with Cryptosporidium parvum infection among children hospitalized for diarrhea in Goiânia, Goiás, Brazil. Amer. J. trop. Med. Hyg., 66: 787-793, 2002.

31. PERZ, J.F. \& LE BLANCQ, S.M. - Cryptosporidium parvum infection involving novel genotypes in wildlife from Lower New York State. Appl. environ. Microbiol., 67: 1154-1162, 2001.

32. ROY, S.L.; DELONG, S.M.; STENZEL, A.S. et al. - Risk factors for sporadic cryptosporidiosis among immunocompetent persons in the United States from 1999 to 2001. J. clin. Microbiol., 42: 2944-2951, 2004.

33. SABESP - Companhia de Saneamento Básico do Estado de São Paulo. Bol. Contr. Mananciais, (Agosto), 2001 
CARVALHO-ALMEIDA, T.T.; PINTO, P.L.S.; QUADROS, C.M.S.; TORRES, D.M.A.G.V.; KANAMURA, H.Y. \& CASIMIRO, A.M. - Detection of Cryptosporidium sp. in non diarrheal faeces from children, in a day care center in the city of São Paulo, Brazil. Rev. Inst. Med. trop. S. Paulo, 48(1): 27-32, 2006.

34. SAREDI, N. \& BAVA, J. - Cryptosporidiosis in pediatric patients. Rev. Inst. Med. trop. S. Paulo, 40: 197-200, 1998.

35. SCHNACK, F.J.; FONTANA, L.M.; BARBOSA, P.R. et al. - Enteropatógenos associados com diarréia infantil ( $<5$ anos de idade) em amostra da população da área metropolitana de Criciúma, Santa Catarina, Brasil. Cad. Saúde públ., 19: 12051208, 2003.
36. SODRÉ, F.C. \& FRANCO, R.M.B. - Novos aspectos sobre um tema bem conhecido: Cryptosporidium. Rev. bras. Anál. clín., 33: 97-107, 2001.

37. WIEBBELLING, A.M.; MEZZARI, A.; SCHENATO, L.K; RICHTER, V.T. \& BOHME, E.S. - Avaliaçäo do conhecimento sobre criptosporidiose em uma amostra de médicos de Porto Alegre, Rio Grande do Sul. J. bras. Pat. Med. Lab., 38: 119-123, 2002.

Received: 24 March 2005

Accepted: 3 October 2005 